IZA DP No. 602

Migration in the Soviet Successor States

Lilo Locher

October 2002 


\title{
Migration in the Soviet Successor States
}

\author{
Lilo Locher \\ IZA Bonn and University of Bonn
}
Discussion Paper No. 602
October 2002

\author{
IZA \\ P.O. Box 7240 \\ D-53072 Bonn \\ Germany \\ Tel.: +49-228-3894-0 \\ Fax: +49-228-3894-210 \\ Email: iza@iza.org
}

This Discussion Paper is issued within the framework of IZA's research area Internationalization of Labor Markets. Any opinions expressed here are those of the author(s) and not those of the institute. Research disseminated by IZA may include views on policy, but the institute itself takes no institutional policy positions.

The Institute for the Study of Labor (IZA) in Bonn is a local and virtual international research center and a place of communication between science, politics and business. IZA is an independent, nonprofit limited liability company (Gesellschaft mit beschränkter Haftung) supported by the Deutsche Post AG. The center is associated with the University of Bonn and offers a stimulating research environment through its research networks, research support, and visitors and doctoral programs. IZA engages in (i) original and internationally competitive research in all fields of labor economics, (ii) development of policy concepts, and (iii) dissemination of research results and concepts to the interested public. The current research program deals with (1) mobility and flexibility of labor, (2) internationalization of labor markets, (3) welfare state and labor market, (4) labor markets in transition countries, (5) the future of labor, (6) evaluation of labor market policies and projects and (7) general labor economics.

IZA Discussion Papers often represent preliminary work and are circulated to encourage discussion. Citation of such a paper should account for its provisional character. A revised version may be available on the IZA website (www.iza.org) or directly from the author. 
IZA Discussion Paper No. 602

October 2002

\section{ABSTRACT}

\section{Migration in the Soviet Successor States*}

This paper analyzes the migration behavior of ethnic groups in the former Soviet Un-ion (FSU) from 1989 to 1999. The two main migration movements have been return migration of ethnic groups to their titular nation and migration of all ethnic groups to the Russian Federation. Using factor analysis, we are able to disentangle the effects of economic wealth, growth, and political reforms on migration behavior. Ethnic sorting is found to be the major determinant of migration, which can explain both return migration and migration to Russia. The emigration behavior of Jews and ethnic Germans is found to be very similar to the migration behavior of ethnic groups migrating within the FSU.

JEL Classification: F22, J15, P26

Keywords: $\quad$ CIS, place-to-place migration, nationality/ethnicity, minorities

Corresponding author:

Lilo Locher

IZA

P.O. Box 7240

D-53072 Bonn

Germany

Tel.: +492283894531

Fax: +492283894510

Email: locher@iza.org

\footnotetext{
* We would like to thank Tim Heleniak for providing the data. Participants of two Brown Bags and two anonymous referees made very important and helpful comments.
} 


\section{Introduction}

In the 1990s, large population movements in and out of the former Soviet Union (FSU) took place as a consequence of the breakdown of the Communist regime. Several million people of different nationalities left their country of residence for their titular country or migrated to Russia. In terms of numbers, the biggest movement was the migration of 2.7 million ethnic Russians to the Russian Federation between 1989 and 1999. Apart from movements between countries of the FSU, a mass exodus of members of national groups who had the opportunity to leave the commonwealth for a rich Western country was taking place. Close to 2 million ethnic Germans migrated to Germany. More than one million Jews left, mainly for Israel, but also for the US and Germany.

This paper investigates migration between and out of the newly founded countries of the FSU, focusing on the impact of nationality. In the FSU, people have both their citizenship and their nationality reported in their passport. The nationality defines to which ethnic group someone belongs and is determined by the nationality of her parents. Rules about the determination of a child's nationality in case her parents belong to different nationalities vary between countries, nationalities, and over time. In Soviet times as well as today, a person's nationality plays an important role due to open and disguised discrimination against members of certain ethnic groups. As nationalities reflect ethnicities, we use the terms "ethnicity" and "nationality" as synonyms in this paper.

Using data on net migration rates of ethnic groups between and out of the FSU countries from 1989 to 1999 we investigate the role of economic variables, of indicators for political stability and transition, of country and ethnic group size as determinants of migration. First, we expect people to migrate from less to more successful countries with regard to economic and political transition. Next, we expect a negative spurious correlation between the size of a country and migration rates, because larger countries should tend to encompass a relatively larger share of movements within their own boundaries (cf. Schultz, 1982, p. 573). These are disregarded in our data. Last, we expect migration to take place in a way that leads to a sorting of ethnic groups. This is because people seem to have a preference for living surrounded by members of their own ethnic group. Also, governments might foster policies of ethnic sorting. We will discuss these points in more detail in the second section of this paper. 
So far, the literature on post-Soviet migration concentrated on the discussion of two main trends (Robertson, 1996). First, ethnic groups migrate to the newly independent nations in which they form the titular group. These movements are denoted as return migration. Indeed, the overwhelming majority of these migrants originate from their country of destination, which they or their parents left - voluntarily or involuntarily - under the Soviet regime. Figures 1 and 2 depict the respective numbers. Net migration rates for ethnic groups to their national state from 1989 to 1999 are positive in 13 out of 15 cases, with Georgia and Estonia as the only exceptions. Most of the attention in the literature was given to the return migration of ethnic Russians to Russia (Brubaker, 1998; Flynn, 2002). As can be seen in figure 1, in terms of numbers this is indeed by far the largest movement, exceeding the depicted scale by a multiple. However, Russians also are by far the largest national group in the FSU. Comparing net migration rates, the migration rate of Russians to Russia is only sixth in size, with an increase of the Russian population in Russia through migration by $2.2 \%$. Figure 2 shows that Belarus, Tajikistan, Kazakhstan, Armenia and Turkmenistan experienced higher rates of return migration than Russia.

The second trend that has been discussed in the literature is migration to the Russian Federation by members of all nationalities. Figures 3 and 4 depict the respective data. In terms of numbers, Armenians, Ukrainians and Tatars have migrated the most to Russia, apart from ethnic Russians, of course. Looking at figure 4, which relates the numbers to the size of the national groups in the Russian Federation in 1989, we see that Transcaucasian and Central Asian national groups experienced particularly large in-migration to Russia. Yet, note that Russia also experienced net immigration from two out of three Baltic countries.

The common explanation for return migration of people to their own titular nation is stated to be a preference for living in one's own nation. The explanations that are put forward for migration to Russia are Russia's good economic performance as compared to other CIS countries and the condemnation of the Russian culture outside Russia. Since the breakdown of the Soviet Union, the newly founded states of the FSU have been reviving their own culture. Being a member of the titular nationality is graded up, and members of other nationalities, among them Russians, have to assimilate. In particular, the official language is not Russian any more, but solely the language of the respective newly founded nation, which makes life difficult for those 
who do not share the titular nationality of their country of residence. ${ }^{1}$ Thus, given this sudden change in policy, it is not surprising if those who assimilated to the Russian culture react by migrating to Russia, where Russian remained the official language. Russian policy makers, on the other hand, are quite open to accept these migrants, even if they are not of Russian nationality (Flynn, 2002).

The goal of this paper is to analyze more closely the reasons for migration within the FSU. So far, research on migration within the FSU has concentrated on case studies (Heleniak, 2002; Robertson, 1996). Though interesting, these papers do not provide an econometric analysis testing for common features in the different countries' migration waves. In contrast to that, we neglect the idiosyncrasies of different countries, but try to filter out some universal patterns. We confront different explanations given in the literature for return migration and migration to Russia with a single explanation for both phenomena, namely ethnic sorting. Ethnic sorting takes place if people migrate from countries in which their ethnic group is small to countries in which their ethnic group is larger. This may explain migration to Russia and return migration at the same time, because usually the two largest subgroups of a national group live in their titular nation and in Russia. Assessing the relative importance of three explanations for migration to Russia, namely ethnic sorting, condemnation of the Russian culture outside Russia, and Russia's economic success; we find that ethnic sorting can explain almost all the effect of migration to Russia, whereas the two other points play a minor role.

As to emigration from the FSU, our results indicate that it is determined in the same way as migration within the FSU. Migration rates of ethnic Germans and Jews have been slightly higher than those of other ethnic groups. However, the difference is surprisingly small, even if we do not correct for the high gap in wealth between the FSU countries on the one side and Germany, Israel and the US on the other side. Apart from Germans, Jews and the 15 national groups of the 15 constituent states of the FSU, there are three other national groups depicted in figures 3 and 4, namely Tatars, Bashkirs, and Chuvashs. In the 1989 Census, the Soviet Union listed 128 na-

\footnotetext{
${ }^{1}$ For example, a good command of Kazakh is a necessary condition for a job in the public sector in Kazakhstan nowadays, in spite of the fact that many Kazakhs are more fluent in Russian than in Kazakh. Even worse, less than one percent of Ukrainians and Russians in Kazakhstan, which made up more than $40 \%$ of the population in 1989, are able to communicate in Kazakh (Khazanov, 1995). Belarus and Kyrgyzstan are the only countries in the FSU, which have both Russian and their titular nation language as official languages.
} 
tional groups. Some of these groups are of considerable size. The largest among them, the Tatars, has 6.6 Mio members, which means that they outnumber nine out of the 15 national groups that have a constituent state (Vishnevsky, 2002). Many national groups who do not form a constituent state own an autonomous republic, region, or district (rayon) instead, usually located within the Russian Federation. In our estimations, we try to distinguish between return migration and migration to another FSU country. However, for these groups, this is not possible. Migration of Tatars to Russia may be return migration, if they migrate to their autonomous republic within the Russian Federation, Tatarstan, but it may also be migration to a region in Russia that does not belong to Tatarstan. What is more, we cannot observe migration within Russia to Tatarstan in our data. ${ }^{2}$

The rest of the paper is structured as follows. In section 2, we discuss economic and ethnic reasons for migration in the FSU. In section 3, we introduce the data and discuss our estimation methods. In section 4, we present the results. Section 5 concludes.

\section{Who goes where? Reasons for migration}

\subsection{Economic reasons}

The first reason for migration between and out of FSU countries may be differences in expected lifetime earnings. Utility maximizing individuals migrate to the place offering the highest expected future income stream. Differences in expected lifetime earnings are a common motivation for migration in economic models of migration. The models by Harris and Todaro (1970) and Borjas (1987), to quote two out of many examples, have been tested empirically in a series of papers about internal migration. Fields (1979) discusses the choice of different labor market variables measuring expected income. Schultz (1982) and Borjas et al. (1992) concentrate on the migration behavior of different educational strata, both regarding the direction and the size of migratory movements.

There is no reliable labor market data available for all successor states of the Soviet Union, and of course, the data we have does not allow us to split up people according

\footnotetext{
${ }^{2}$ For population movements within the Russian Federation see Heleniak (1999). Migration from the poor and underdeveloped Transcaucasian and Central Asian countries to Russia takes place analogically within Russia. People move from the relatively poor Russian North to the western and
} 
to their educational level. However, we expect people from all ethnic groups to tend moving to countries that have a higher GDP per capita, higher growth rates, and perform relatively well in transition and institutional quality indices. With respect to all these measures, there are considerable differences between the countries of the FSU. In general, the Baltic countries and Russia are relatively well off, whereas Central Asian countries like Turkmenistan, Tajikistan and Uzbekistan form the taillight. There are several ethnic groups in the Soviet Union that have the possibility to emigrate to a country outside the FSU. For those among them who could migrate to a rich Western economy, i.e. Finns, Germans, and Jews, economic reasons for migration seem particularly convincing due to the huge economic difference as opposed to differences within the FSU. If migration takes place due to this reason, every ethnic group should migrate in the same direction, from poor to rich countries. Note that this might be a reason for the immigration of so many different national groups to Russia.

\subsection{Ethnic reasons}

Ethnic return migration, i.e. migration of people to their newly founded titular nation, is different from migration for economic reasons, because it motivates migration in different, even opposing directions by different ethnic groups. For instance, Tajiks migrate from Armenia to Tajikistan, while at the same time Armenians migrate from Tajikistan to Armenia. Of course, ethnic migration is not restricted to return migration. There may also be migration by Tajiks, for example, from Armenia to Russia in order to join the Tajik community in Russia. We are able to observe this kind of migration in our data, because we have net migration rates by ethnic groups.

Ethnic sorting through migration takes place if individuals are willing to move in order to live in a society in which their ethnic group holds a high percentage of the population. There are a number of reasons why people may have a preference for being surrounded by co-ethnics. Ethnic groups may have common norms, customs, and a common language, which facilitates social life to a considerable degree. We do not go further into that here, instead, we discuss two reasons why, given individuals have this kind of preferences, governments might also be interested in ethnically homogeneous populations and thus adopt policies that enhance ethnic sorting. The first claims

southern parts of the country. However, we could not find any evidence for ethnic return migration within the Russian Federation in the 1990s. 
that the deadweight loss of collecting income taxes is lower in more homogeneous societies, because the costs of tax evasion through emigration are higher. The second claims that government spending is more efficient in homogeneous societies, because there are less coordination problems.

First, consider the collection of labor income taxes in societies allowing their citizens to emigrate. As tax evasion is possible by leaving the country, governments are exposed to tax competition. If they do not want to carry a large deadweight loss, they either have to diminish tax rates, or they have to make tax evasion more difficult. As a democratic government cannot force its citizens to stay, it has to create incentives that make people stay and pay higher tax rates voluntarily. Concerning labor taxes, it can ensure that emigration costs are high. This is the case if political borders coincide with cultural and linguistic borders, an argument which can be traced back to Friedman (1977). ${ }^{3}$

As a second argument, note that the way tax income is spent also depends on the ethnic structure of a society. Let government spending be determined by the lobbying of interest groups, who are confronted with a group of political decision makers. There is a series of models showing that coalitions among interest groups and among political decision makers usually improve the result from a welfare-maximizing point of view (Easterly and Levine, 1997). The underlying idea is that a particular interest group or a decision maker does not take into account the effect of her decision on other interest groups or decision makers. In ethnically fragmentized societies, coalitions usually are much harder to realize. While the majority of empirical papers about the consequences of ethnic fragmentation compare cities or even smaller entities, Easterly and Levine (1997) provide evidence on the country level. They show that ethnic diversity has a significant negative impact on growth enhancing public policies. In particular, Africa's high ethnic diversity is able to explain a considerable part of growth rate differences between African countries versus countries in South America and the Far East.

The two arguments presented here may explain why many governments in the FSU have laws and rules that enhance migration that leads to ethnic sorting. Immigration of co-ethnics is fostered, whereas there is not much being done to obviate

\footnotetext{
${ }^{3}$ According to this argument it is not important that there is only one national group living in a country. The crucial point is that all members of a national group live within one country, so that they cannot switch.
} 
emigration by members from other ethnic groups. ${ }^{4}$ A necessary condition for these rules to work, however, is a preference of individuals to live together with co-ethnics. Given that this is the case, these rules can enhance the degree to which ethnic sorting takes place.

\section{Data and estimation methods}

\subsection{The data}

The data set we use consists of about 80 migration movements of ethnic groups from or to a FSU country from 1989 to $1999 .{ }^{5}$ The data set is constructed compiling census statistics in the respective countries and splitting up population changes in changes due to natural increase or due to migration. ${ }^{6}$ Unfortunately, the census statistics only report the number of people entering or leaving the country, they do not have information on where they go or from where they come. Therefore, we are not able to include both source country and destination country characteristics as explanatories into the estimation of the migration function. The data for the dependent variables include information on the ethnic composition of the source or the destination country as well as macroeconomic variables and indices measuring wealth, economic growth, political stability, and speed of transition.

\subsection{Specifications of the migration function}

We use two specifications to estimate migration functions. First, we do a Heckman FIML (Full information maximum likelihood) with migration rates as the dependent variables. Second, we estimate the number of immigrants and the number of emigrants separately, including the denominator of the migration rate, i.e. the base population, as a dependent variable in the respective estimations.

\footnotetext{
${ }^{4}$ For example, the newly founded countries declared the language of their titular nationality as the only official language, discriminating against the Russian language, which would make their citizens more mobile. In the Baltic countries, it was difficult for residents that did not belong to the titular ethnic group to obtain citizenship. Even though Russians made up about one third of the population in Estonia and Latvia, the countries adopted the ius sanguinis as the basis for citizenship, and language tests were required for non-titular nationalities to become citizens.

${ }^{5}$ We are indebted to Tim Heleniak for kindly providing us the data. See Heleniak (1997 and 2002, tables 5-19) for analogous data in the period 1989-1996. There is no data on immigration from outside the FSU into FSU countries, because there was none.

${ }^{6}$ In the future, there will be three components of population change: natural increase, net migration and ethnic re-identification. The introduction of the last category shows how problematic it is to assign nationalities to people. However, as nationalities play an important role in explaining migration within the FSU, using bad data is better than ignoring nationality affiliations.
} 
For the estimation of migration rates, we take the number of immigrants or emigrants from an ethnic group divided by the size of the ethnic group in the source or destination country, respectively, as the dependent variable. As mentioned before, we have information on 80 migration movements. However, in principle, there are much more, because 15 nations and 128 ethnic groups are involved. So there is selection with respect to the endogenous variable in the data. It is possible to get information about the population share of ethnic groups who made up more than about $1 \%$ in 1989 for every country. Thus, to correct for the selection, we incorporate that information whenever the respective migration variable was missing. Having included about 30 censored observations in the data set, we do a Heckman correction with FIML. ${ }^{7}$ The main selection variable we use is the overall size of the respective national group in the Soviet Union. Smaller groups are less likely to be included in the migration data, but they are not less likely to migrate. The $\mathrm{R}^{2}$ of a regression of the inverse Mills ratio on the regressors of the outcome equation, as suggested by Puhani (2000) to see whether the correction works, is still quite large, so we also tried simple OLS regressions. Results did not change much. If possible, we also include a dummy for return migration of the titular group as a selection variable, as this is something countries would always report. $^{8}$

Having information only on either the source or the destination country is a severe caveat of our data. Running estimations with all observations, including either information on the country or origin or the destination country, as we do it for the Heckman FIML, has several problems: First, it is hard to find a good correction for different sizes of the populations of potential migrants. We use net migration rates as the dependent variable, defined as the number of immigrants divided by the size of the national group in the receiving country, or as the number of emigrants, divided by the size of the national group in the sending country. Practically, this works quite well as a correction for size. Yet, there are some problems. First, the dependent variable has a support restricted to $[-1,0]$ for net emigration rates, so that the total support of the dependent variable is $[-1, \infty)$. In contrast to that, the regression model assumes the support of the dependent variable to be $(-\infty, \infty)$. Second, running a joint regression for

\footnotetext{
${ }^{7}$ In small samples, a FIML estimator seems to perform better than a two-step procedure (Nawata, 1994).

${ }^{8}$ Note that we still do not correct for the fact that ethnic groups that make up less than about $1 \%$ of a country's population are not in the sample. We have to interpret results conditional on the ethnic group being of a certain minimum size.
} 
emigration and immigration assumes the independent variables to act equally strong as push and as pull factors. This assumption has been rejected in previous estimations of place-to-place migration functions (Fields, 1979). Finally, there may be a considerable number of double counting. For instance, Russians who migrate from Tajikistan to Russia are represented both as emigrants from Tajikistan and as immigrants to Russia. Nevertheless, we present one table of regressions using both net emigration and immigration rates in the same regression.

A simple OLS regression with either the number of immigrants or the number of emigrants as the dependent variable solves these problems. Therefore, our second specification of the migration function uses the logarithm of the number of immigrants or emigrants, respectively, as the dependent variable. To correct for size, we include the logarithm of the number of potential migrants as a variable on the right hand side. We define the number of potential immigrants as the size of the ethnic group in the whole Soviet Union, reduced by the size of the ethnic group in the receiving country itself. The number of potential emigrants is the size of the ethnic group in the sending country. If ethnic sorting does not play a role for migration, the coefficient for the potential migrants variable should be equal to one. In both cases, the support of the dependent variable is $(-\infty, \infty)$. Obviously, we get the impact of push factors in the immigration estimation, and the size of pull factors in the emigration estimation. Also, double counting is not possible in this case. The caveat of this approach is that we split a small data set in two, so that the number of observations reduces to 26 for immigration and 53 for emigration. Also, it is not possible to do a Heckman correction, as it is not clear whether observations that are not in the data set are excluded ore missing. Finally, note that the $\mathrm{R}^{2}$ in this specification is expected to be very high due to the way we correct for size.

There are only net migration movements in our data. However, using net instead of gross rates is not too much of a problem in this analysis. As we are able to split up the migration to and from one country by nationality, we often have negative and positive numbers for the same country, and as most of the migration movements of a given nationality are in one direction, gross rates are not very different from net rates. The numbers are not only "net" in the sense that they are the difference between immigration and emigration, they are also "net" in a temporal sense. If people leave a 
country in a particular year in the beginning of the 1990s, maybe because of a civil war, but return one or two years later, they do not show up in our data.

\subsection{Explanatory variables}

As mentioned in section 2.1, we expect migration rates to depend on the economic success and the progress in transition in the different FSU countries. Also, the Russian Federation seems to play a particular role in FSU migration. The variables one would like to use in order to measure these things are all highly correlated with each other. Table 1 presents the respective numbers. We use data from different institutions and slightly different concepts to measure GDP and growth. ${ }^{9}$ The EBRD Transition Indicator ${ }^{10}$ reflects economic transition along three dimensions. It measures the degree of privatization, market liberalization and financial market reforms. The Baltic countries perform best, Belarus and Turkmenistan worst. The index of institutional quality ${ }^{11}$ is derived from a huge data set with several hundred indicators of various aspects of governance. Kaufmann et al. (1999) compile these indicators into six components of government performance, e.g. "political instability and violence" or "graft". The index we use is the arithmetic mean of all six components. Again, the Baltic countries perform best, whereas Tajikistan, Turkmenistan and Uzbekistan perform worst. In both indices, the Russian Federation is somewhere in the middle, whereas Russia is second in terms of GDP per capita.

To avoid multicollinearity problems in the estimation, we use factor analysis to compile the eight variables presented in table 1 into four factors, such that we are able to attach an interpretation to each factor. Table 2 presents the factor loadings of the four factors. ${ }^{12}$ We call the first factor "growth", because factor loadings are very high for the two growth variables. The second factor is called "wealth", as factor

\footnotetext{
${ }^{9}$ GDP is measured per capita; growth rates are corrected for changes in population size. Data from countries of the former Soviet Union tend to be seriously flawed. We use data from different institutions, hoping that idiosyncratic errors cancel out in the factor analysis.

${ }^{10}$ Source: EBRD Transition Report 1999, table 2.1, or World Economic Outlook 2000, table 3.9

${ }^{11}$ Source: World Economic Outlook 2000, table 3.11, which is a rescaled version of Kaufmann et al. (1999).

${ }^{12}$ The factor analysis calculates factor loadings as to maximally reproduce the correlations between the variables included. Due to the indeterminate nature of the factors, there are an infinite number of solutions. Thus, it is legitimate to choose a solution, which has a nice economic interpretation. The uniqueness, which reflects the portion of variance that is left over in a variable, reflects the sum of the specificity of that variables and the measurement error (Harman, 1976). In this case, the value for the uniqueness is very low for every variable, so that we hardly lose any information by using factor analysis.
} 
loadings for the two GDP level variables are very high. Note that the index of institutional quality also goes in there. The third factor is called "transition", as there are high factor loadings for the two transition indices. We name the last factor "Russia". It could as well be called "size", as both the size of population variable and the Russia dummy enter with a high weight. We are not able to discriminate between the two. We write the names of the four new variables in quotation marks, because they measure the respective economic variable only conditional on that variable being orthogonal to the three other factors.

The data set is not large enough to include country dummies or nationality dummies. However, we split up the FSU countries into four relatively homogeneous regions and include these regions as dummies. Nationality dummies we included for large national groups turned out to be insignificant. Furthermore, we allow standard errors not to be independent across observations for the same country. ${ }^{13}$

\section{Results}

\subsection{Results for the whole sample}

First, we present the Heckman FIML estimations with the migration rate as the dependent variable. Table 3 depicts the estimation results using the whole sample and the sample excluding observations of national groups migrating to or from their titular nation. The first estimation says that the emigration rate is lower and the immigration rate is higher if an ethnic group in the respective country is larger. This indicates that there is ethnic sorting. The three national groups that may emigrate to a Western economy, Finns, Germans and Jews, have emigration rates that are particularly high. Three out of the fours factors drawn from the factor analysis are significant and have the expected sign. The selection variables are highly significant, however, Heckman's Lambda is not. The Wald test of independent equations cannot be rejected on the 5\% level. This indicates that neglecting sample selection for our estimations with a split sample may not be too serious a problem.

The last two columns in table 1 show that reestimating the equations with the reduced sample does not change results very much. However, the coefficient on the share of the ethnic group turns out to be insignificant now. So it seems that in the first

\footnotetext{
${ }^{13}$ Alternatively, it makes sense to allow standard errors not to be independent across nationalities. However, as it turns out, results are robust to changes in the specification of the clustering structure.
} 
estimation, this just covered the fact that the there is a lot of return migration, and at the same time the share of the migrant's national group is very high in her titular country. To see whether emigration of Finns, Germans and Jews is due to the economic differences between the CIS and their rich Western titular nations, we replace their dummy by the per capita GDP in PPP in 1999 of the titular nation of the respective national group. This variable is supposed to measure the wealth difference between the emigration and the immigration country. Obviously, there is a lot of measurement error in this variable, as not all migration is return migration. The coefficient of the variable is highly significant, but a comparison of the log likelihood values of the two specifications shows that a dummy is superior to the GDP variable.

As discussed in section 3, all estimations in table 3 do not take into account that there may be double counting of some migration movements. Also, the support of the dependent variable has a lower bound of -1 . We present the estimations because they correct for selection and because they use the whole sample. However, the results should be interpreted with care.

\subsection{Results for immigration}

Table 4 presents five specifications for estimations of in-migration with the log number of immigrants as the dependent variable. As the sample size is so small, specifications (2) and (3) repeat the first specification omitting the region dummies, which are insignificant anyway. Specifications (4) and (5) use different variables than the first three specifications to measure the degree to which ethnic groups pull co-ethnics in their country. Due to the small sample size, the estimated coefficients for the four factor variables vary considerably across specifications. We do not find a positive influence of economic success on immigration. In specification (2), we find that a higher success in transformation decreases immigration, which is the opposite of what one would expect. To explain that, note that within the CIS, there is free movement of labor, whereas this does not hold for the Baltic countries. Therefore, it may be that the negative coefficient for transition reflects the fact that people do not immigrate to the Baltic countries, which at the same time are very successful concerning the degree of transition. Therefore, specification (3) repeats specification (2), omitting the observations for the Baltic countries. In fact, the transition coefficient turns insignificant. 
According to all specifications, there is a huge degree of ethnic sorting. To see this, think of migration as being completely independent of ethnicity. In this benchmark case, the coefficient of the first variable, the log of the number of potential immigrants, should equal one. ${ }^{14}$ The coefficient of the different measures for the representation of the ethnic group in the receiving country should equal zero. In contrast, ethnic sorting means that people rather leave if they form a small group, and they tend to move to a country in which they form a large group. In fact, the elasticity of immigration with respect to potential immigration is about 0.32 in all specifications, which is far below 1. On the other hand, a high impact of the ethnic group in the receiving country is a very strong push factor. In specification (1), the elasticity of immigration with respect to the ethnic group in the receiving country is estimated to be 0.78 .

To be more specific about what makes migrants move to groups of the same ethnicity, we use two other variables for the impact of the ethnic group in specifications (4) and (5). In specification (4), we replace the size of the ethnic group in the immigration country by a dummy for return migrants. The coefficient for this dummy is positive and highly significant, and at the same time, the coefficient for "Russia" gets more than four times as large as in specification (1) and also turns highly significant. The two coefficients cover the two effects of ethnic return migration and migration to Russia. However, comparing the $\mathrm{R}^{2} \mathrm{~s}$ shows that the first specification, which allows for ethnic sorting as a common explanation for the two phenomena, is superior to specification (4). Finally, specification (5) uses the share of the ethnic group with respect to the whole population in the receiving country as a measure for the gravity of the ethnic population in the destination country. The coefficient for "Russia" is smaller now, but still significant, and the $\mathrm{R}^{2}$ is the same as for specification (4).

\subsection{Results for emigration}

Table 5 presents five specifications for estimations of out-migration. The dependent variable is the log number of emigrants. The number of observations is roughly twice the number we have for the estimations of in-migration, and results are more robust. In specification (1), we include the size of an ethnic group outside the source country

\footnotetext{
${ }^{14}$ The coefficient can be interpreted as the marginal elasticity of immigration with respect to the size of the population of potential immigrants.
} 
in the FSU as an explanatory variable. In specifications (2) to (5) we replace this variable by the total size of an ethnic group outside the source country. Of course, this makes a big difference for those groups who have a titular nation outside the FSU. The dummy for Finns, Jews and Germans is much smaller in specifications (2) to (5), and in three out of four cases it is only significant at the $10 \%$ level. It seems that even without including a variable that reflects the wealth of Finland, Israel, Germany, and the US as opposed to the FSU, the extent to which these groups emigrate is hardly different from that of other groups.

Specifications (3) and (4) repeat specification (2), only that (3) omits region dummies and (4) omits the four factor variables. Without region dummies, "wealth" and "transition" decrease emigration significantly, so that there is an effect of economic indicators on migration behavior here. Specification (5) includes the share of the titular population in the source country. The respective coefficient is insignificant. It may be that two effects cancel each other here. On the one hand, ethnically homogeneous societies seem to be advantageous, as discussed in section 2.2. On the other hand, a large titular group in a country may lead to less respect concerning the rights of minorities.

Again, there is evidence for a large degree of ethnic sorting across all specifications. In the benchmark case of random migration, the elasticity of emigration with respect to the size of the ethnic group in the source country should equal one, whereas the elasticity of emigration with respect to the size of the ethnic group outside the emigration country should equal zero. As opposed to that, we estimate the first elasticity to be less than 0.7 , the latter one to be around 0.4 . Both coefficients are significantly different from the no sorting benchmark values, one and zero, respectively. The coefficient for "Russia" is insignificant.

In table 6 , we investigate the migration behavior of ethnic Germans and Jews more closely. Column (1) has the size of the FSU ethnic population outside the emigration country as an explanatory variable. In this case, the dummies for Jews and for Germans both are significantly positive. Column (2) has the total size of the ethnic population outside the emigration country as a dependent variable. As the number of Germans is about six times the number of Jews, it is not surprising that the dummy for Jews is significantly positive here, whereas the German dummy is not. In both estimations, the difference between the two dummy coefficients is not significant, so that 
we cannot reject the hypothesis that Jewish and German emigration are equal in these estimations.

\section{Concluding remarks}

So far, two aspects of FSU migration in the 1990s have been discussed in the literature. The first one is return migration of national groups to their titular nations; the second one is immigration to Russia by most ethnic groups of the FSU. We interpret the two as two consequences of one common phenomenon, namely ethnic sorting, and discuss several reasons of why ethnic sorting may take place.

In the empirical part of the paper, we find strong evidence for ethnic sorting through migration. There is more emigration if the size of the respective ethnic group in the source country is smaller, and migrants tend to move to countries in which their own ethnic group already has a large size. Obviously, the latter effect implies that return migration plays an important role. Also, ethnic sorting can explain immigration to the Russian Federation. As almost all ethnic groups have a relatively large community in Russia, migration to Russia almost always has a sorting effect. Thus, we do not find evidence for Russia to be a special case. In addition to ethnic reasons for migration, we include variables to measure the different economic performance of the countries involved in the migration process and find that both the degree of transition and the wealth level of a country play a role in explaining migration patterns.

\section{Literature}

Borjas, George J. (1987): Self-Selection and the Earnings of Immigrants, American Economic Review 77(4), 531-553.

--- (1992): Self-Selection and Internal Migration in the United States, Journal of Urban Economics 32, 159-185.

Brubaker, Rogers (1998): Migrations of Ethnic Unmixing in the "New Europe", International Migration Review 32(4), 1047-1065.

Easterly, William and Ross Levine (1997): Africa's Growth Tragedy: Policies and Ethnic Divisions, Quarterly Journal of Economics, 451(4), 1203-1250.

European Bank for Reconstruction and Development (1999): Transition Report 1999, London, EBRD. 
Fields, Gary S. (1979): Place-to-Place Migration: Some New Evidence, review of Economics and Statistics, 21-32.

Flynn, Moya (2002): Returning Home? Approaches to Repatriation and Migrant Resettlement in Post-Soviet Russia, in: Rainer Münz und Rainer Ohliger (eds.): "Diasporas and Ethnic Migrants: Germany, Israel and Post-Soviet Space in Comparative Perspective", Oxford: Frank Cass, forthcoming 2002.

Friedman, David (1977): A Theory of the Size and Shape of Nations, Journal of Political Economy 85(1), 59-77.

Harman, Harry H. (1976): Modern Factor Analysis, $3^{\text {rd }}$ edition, Chicago, University of Chicago Press.

Harris, John R. and Michael P. Todaro (1970): Migration, Unemployment and Development: A two-Sector Analysis, American Economic Review 60(1), 126-142.

Heleniak, Tim (2002): The End of an Empire: Migration and the Changing Nationality Composition of the Soviet Successor States in: Rainer Münz und Rainer Ohliger (eds.): "Diasporas and Ethnic Migrants: Germany, Israel and Post-Soviet Space in Comparative Perspective", Oxford: Frank Cass, forthcoming 2002.

---(1999): Out-Migration and Depopulation of the Russian North during the 1990s, Post-Soviet Geography and Economics 40(3), 155-205.

---(1997): The Changing Nationality Composition of the Central Asian and Transcaucasian States, Post-Soviet Geography and Economics 38(6), 357-378.

International Monetary Fund (2000): World Economic Outlook October 2000, Focus on Transition Economies, IMF, Washington.

Kaufmann, Daniel, Aart Kraay, Pablo Zoido-Lobatón (1999): Aggregating Governance Indicators, World Bank Discussion Paper No. 2195.

Khazanov, Anatoly M. (1995): After the USSR: Ethnicity, Nationalism and Politics in the Commonwealth of Independent States, University of Wisconsin Press, United States.

Kurthen, Hermann (1995): Germany at the Crossroads: National Identity and the Challenges of Immigration, International Migration Review 29(4), 914-938.

Nawata, Kazumitsu (1994): Estimation of sample selection bias models by the maximum likelihood estimator and Heckman's two-step estimator, Economics Letters 45(1), 33-40.

Puhani, Patrick A. (2000): The Heckman Correction for Sample Selection and Its Critique, Journal of Economic Survey 14(1), 53-68.

Robertson, Lawrence R. (1996): The Ethnic Composition of Migration in the Former Soviet Union, Post-Soviet Geography and Economics 37(2), 113-128.

Schultz, T. Paul (1982): Lifetime Migration within Educational Strata in Venezuela: Estimates of a Logistic Model, Economic Development and Cultural Change 30(3), 559-593. 
Vishnevsky, Anatoly (2002): The Dissolution of the Soviet Union, Ethnic Migration and the Problem of Diasporas, in: Rainer Münz und Rainer Ohliger (eds.): "Diasporas and Ethnic Migrants: Germany, Israel and Post-Soviet Space in Comparative Perspective", Oxford: Frank Cass, forthcoming 2002. 


\section{Tables and Figures}

Table 1: Pairwise correlation for economic and size variables

\begin{tabular}{|c|c|c|c|c|c|c|c|c|}
\hline & $\begin{array}{c}\text { GDP } \\
\text { growth } \\
1990- \\
1999\end{array}$ & $\begin{array}{c}\text { Real } \\
\text { output } \\
\text { ratio } \\
1999 / \\
1990\end{array}$ & $\begin{array}{c}\text { PPP } \\
\text { GDP/ } \\
\text { capita } \\
1999\end{array}$ & $\begin{array}{c}\text { GDP/ } \\
\text { capita } \\
1990\end{array}$ & $\begin{array}{c}\text { EBRD } \\
\text { Tran- } \\
\text { sition } \\
\text { Indi- } \\
\text { cator }\end{array}$ & $\begin{array}{l}\text { Index } \\
\text { of insti- } \\
\text { tutional } \\
\text { quality }\end{array}$ & $\begin{array}{l}\text { Dum- } \\
\text { my for } \\
\text { Russia }\end{array}$ & $\begin{array}{c}\text { Popula- } \\
\text { tion of } \\
\text { FSU } \\
\text { country }\end{array}$ \\
\hline $\begin{array}{c}\text { GDP } \\
\text { growth } \\
1990-1999\end{array}$ & 1 & & & & & & & \\
\hline $\begin{array}{c}\text { Real out- } \\
\text { put ratio } \\
1999 / 1990\end{array}$ & $0.93 *$ & 1 & & & & & & \\
\hline $\begin{array}{c}\text { PPP GDP/ } \\
\text { capita } \\
1999\end{array}$ & $0.49 *$ & $0.42^{*}$ & 1 & & & & & \\
\hline $\begin{array}{c}\text { GDP/ } \\
\text { capita } \\
1990 \\
\end{array}$ & $0.46^{*}$ & $0.29 *$ & $0.91 *$ & 1 & & & & \\
\hline $\begin{array}{c}\text { EBRD } \\
\text { Transition } \\
\text { Indicator }\end{array}$ & $0.42 *$ & $0.20 *$ & $0.36^{*}$ & $0.51^{*}$ & 1 & & & \\
\hline $\begin{array}{l}\text { Index of } \\
\text { institution- } \\
\text { al quality }\end{array}$ & $0.54 *$ & $0.33^{*}$ & $0.59 *$ & $0.72 *$ & $0.90 *$ & 1 & & \\
\hline $\begin{array}{c}\text { Dummy } \\
\text { for Russia }\end{array}$ & -0.08 & -0.10 & $0.46^{*}$ & $0.42^{*}$ & -0.08 & -0.11 & 1 & \\
\hline $\begin{array}{l}\text { Population } \\
\text { of FSU } \\
\text { country }\end{array}$ & -0.09 & -0.09 & $0.40^{*}$ & $0.37 *$ & -0.13 & -0.18 & $0.99 *$ & 1 \\
\hline
\end{tabular}

Note: $*$ significant at the $5 \%$ level

Sources: GDP growth 1990-1999 from World Development Indicators 2001, table 4.1, The World Bank; Output ratio 1999/1990, PPP GDP per capita, and EBRD Transition Indicator from World Economic Outlook 2000, table 3.1. IMF; GDP per capita 1990 from UN Statistical Yearbook, $44^{\text {th }}$ issue 1997, table 22; Index of institutional quality from World Economic Outlook 2000, table 3.11, IMF. 
Table 2: Factor loadings

\begin{tabular}{cccccc}
\hline & "growth" & "wealth" & "transition" & "Russia" & Uniqueness \\
\hline $\begin{array}{c}\text { GDP growth } \\
\text { 1990-1999 }\end{array}$ & $\mathbf{0 . 8 9}$ & 0.24 & 0.28 & -0.06 & 0.07 \\
$\begin{array}{c}\text { Real output ratio } \\
\text { 1999/1990 }\end{array}$ & $\mathbf{0 . 9 9}$ & 0.13 & 0.06 & -0.06 & 0.00 \\
$\begin{array}{c}\text { PPP GDP per } \\
\text { capita 1999 }\end{array}$ & 0.32 & $\mathbf{0 . 8 0}$ & 0.22 & 0.33 & 0.10 \\
$\begin{array}{c}\text { GDP per capita } \\
\text { 1990 }\end{array}$ & 0.18 & $\mathbf{0 . 8 4}$ & 0.38 & 0.30 & 0.03 \\
$\begin{array}{c}\text { EBRD Transition } \\
\text { Indicator }\end{array}$ & 0.13 & 0.15 & $\mathbf{0 . 9 8}$ & -0.05 & 0.00 \\
$\begin{array}{c}\text { Index of Institu- } \\
\text { tional Quality } \\
\text { Dummy for } \\
\quad \text { Russia }\end{array}$ & 0.21 & 0.50 & $\mathbf{0 . 8 1}$ & -0.17 & 0.03 \\
$\begin{array}{c}\text { Population of } \\
\text { FSU country }\end{array}$ & -0.07 & 0.20 & -0.05 & $\mathbf{0 . 9 7}$ & 0.02 \\
\hline
\end{tabular}

Note: Factor loadings are calculated using the maximum likelihood method. 
Table 3: Estimated net migration rates, complete sample and excluding return migration, Heckman selection model (FIML)

\begin{tabular}{|c|c|c|c|}
\hline Main equation & Whole sample & \multicolumn{2}{|c|}{ Excluding return migration } \\
\hline $\begin{array}{l}\text { Population share of own } \\
\text { ethnic group }\end{array}$ & $0.303 * *(0.111)$ & $0.172(0.153)$ & $0.236(0.162)$ \\
\hline Finns, Germans, Jews & $-0.268 * *(0.066)$ & $-0.270^{* *}(0.073)$ & \\
\hline $\begin{array}{l}\text { GDP } 1999 \text { of titular nation } \\
\text { in PPP }\end{array}$ & & & $-0.000 * *(0.000)$ \\
\hline "Russia" & $0.080 * *(0.018)$ & $0.080 * *(0.015)$ & $0.071 * *(0.015)$ \\
\hline "Wealth" & $0.099 * *(0.030)$ & $0.085^{*}(0.038)$ & $0.093 *(0.041)$ \\
\hline "Growth" & $-0.028(0.017)$ & $-0.015(0.024)$ & $-0.016(0.026)$ \\
\hline "Transition" & $0.053 * *(0.016)$ & $0.045^{*}(0.023)$ & $0.044(0.025)$ \\
\hline $\begin{array}{l}\text { Natural rate of growth } \\
1989-1999\end{array}$ & $0.665 * *(0.192)$ & $0.512 * *(0.203)$ & $0.424 *(0.191)$ \\
\hline Baltic country & $-0.060(0.048)$ & $-0.085(0.055)$ & $-0.088(0.059)$ \\
\hline Transcaucasian country & $-0.319 * *(0.070)$ & $-0.511^{* *}(0.092)$ & $-0.508 * *(0.095)$ \\
\hline Central Asian country & $-0.030(0.066)$ & $-0.089(0.075)$ & $-0.065(0.080)$ \\
\hline Constant & $-0.146^{* *}(0.047)$ & $-0.089 *(0.036)$ & $-0.015(0.040)$ \\
\hline \multicolumn{4}{|l|}{ Selection equation } \\
\hline "Russia" & $1.552 * *(0.352)$ & $1.385 * *(0.318)$ & $1.392 * *(0.339)$ \\
\hline "Transition" & $0.945^{*}(0.475)$ & $0.961 *(0.429)$ & $0.922 *(0.411)$ \\
\hline Migration to own country & $11.44 * *(1.292)$ & & \\
\hline Total size of ethnic group & $0.000 * *(0.000)$ & $0.000 * *(0.000)$ & $0.000^{* *}(0.000)$ \\
\hline Baltic country & $8.188^{* *}(0.723)$ & $7.385 * *(0.560)$ & $7.264 * *(0.873)$ \\
\hline Transcaucasian country & $0.712(0.436)$ & $1.118 *(0.484)$ & $0.942 *(0.399)$ \\
\hline Central Asian country & $-0.025(0.373)$ & $0.135(0.370)$ & $-0.146(0.356)$ \\
\hline Constant & $-0.659 * *(0.210)$ & $-0.585^{* *}(0.207)$ & $-0.539 * *(0.207$ \\
\hline Lambda & $-0.065(0.040)$ & $-0.038(0.060)$ & $-0.060(0.066)$ \\
\hline $\begin{array}{l}\text { Wald test of independent } \\
\text { equations }\end{array}$ & Rejected & Not Rejected & Not Rejected \\
\hline Total observations & 112 & 90 & 90 \\
\hline Censored observations & 31 & 28 & 28 \\
\hline Log likelihood & 16.33 & 10.75 & 7.66 \\
\hline
\end{tabular}

Note: Baltic countries are Estonia, Latvia and Lithuania, Transcaucasian countries are Armenia, Azerbaijan and Georgia, Central Asian countries are Kazakhstan, Kyrgyzstan, Tajikistan, Turkmenistan and Uzbekistan, reference group is Slavic countries with Belarus, Moldova, Russia and Ukraine. Standard errors calculated with clustering on countries. $*=$ significant at the $5 \%$ level, $* *=$ significant at the $1 \%$ level, robust standard errors in parentheses. 
Table 4: Estimated immigration (dependent variable: $\log$ of immigrants)

\begin{tabular}{|c|c|c|c|c|c|}
\hline & (1) & (2) & (3) & (4) & $(5)$ \\
\hline $\begin{array}{l}\text { Log of potential } \\
\text { number of } \\
\text { immigrants }\end{array}$ & $\begin{array}{c}0.327 * * \\
(0.054)\end{array}$ & $\begin{array}{c}0.313 * * \\
(0.045)\end{array}$ & $\begin{array}{c}0.301 * * \\
(0.035)\end{array}$ & $\begin{array}{l}0.327 * \\
(0.117)\end{array}$ & $\begin{array}{l}0.344^{*} \\
(0.155)\end{array}$ \\
\hline $\begin{array}{l}\text { Log of ethnic } \\
\text { group size in im- } \\
\text { migration country }\end{array}$ & $\begin{array}{c}0.780 * * \\
(0.030)\end{array}$ & $\begin{array}{c}0.764 * * \\
(0.048)\end{array}$ & $\begin{array}{c}0.761 * * \\
(0.051)\end{array}$ & & \\
\hline $\begin{array}{l}\text { Migration to own } \\
\text { country }\end{array}$ & & & & $\begin{array}{c}4.145 * * \\
(0.152)\end{array}$ & \\
\hline $\begin{array}{l}\text { Share of ethnic } \\
\text { group in im- } \\
\text { migration country }\end{array}$ & & & & & $\begin{array}{c}5.079 * * \\
(0.591)\end{array}$ \\
\hline "Russia" & $\begin{array}{c}0.268 \\
(0.136)\end{array}$ & $\begin{array}{c}0.173 \\
(0.098)\end{array}$ & $\begin{array}{c}0.120 \\
(0.173)\end{array}$ & $\begin{array}{l}1.015 * * \\
(0.191)\end{array}$ & $\begin{array}{l}0.696 * \\
(0.294)\end{array}$ \\
\hline "Wealth" & $\begin{array}{c}0.480 \\
(0.374)\end{array}$ & $\begin{array}{l}-0.066 \\
(0.167)\end{array}$ & $\begin{array}{c}0.034 \\
(0.270)\end{array}$ & $\begin{array}{c}0.161 \\
(0.546)\end{array}$ & $\begin{array}{c}0.677 \\
(0.647)\end{array}$ \\
\hline "Growth" & $\begin{array}{l}-0.127 \\
(0.191)\end{array}$ & $\begin{array}{l}-0.030 \\
(0.185)\end{array}$ & $\begin{array}{c}0.017 \\
(0.205)\end{array}$ & $\begin{array}{c}0.114 \\
(0.120)\end{array}$ & $\begin{array}{l}-0.109 \\
(0.211)\end{array}$ \\
\hline "Transition" & $\begin{array}{l}-0.238 \\
(0.3335\end{array}$ & $\begin{array}{c}-0.497 * * \\
(0.147)\end{array}$ & $\begin{array}{l}-0.410 \\
(0.330) \\
\end{array}$ & $\begin{array}{l}-0.572 \\
(0.496)\end{array}$ & $\begin{array}{l}-0.040 \\
(0.597)\end{array}$ \\
\hline Baltic country & $\begin{array}{l}-0.168 \\
(0.896)\end{array}$ & & & $\begin{array}{l}-0.716 \\
(1.173)\end{array}$ & $\begin{array}{l}-1.336 \\
(1.211)\end{array}$ \\
\hline $\begin{array}{l}\text { Transcaucasian } \\
\text { country }\end{array}$ & $\begin{array}{c}0.776 \\
(0.575)\end{array}$ & & & $\begin{array}{c}0.192 \\
(0.649)\end{array}$ & $\begin{array}{l}-0.447 \\
(0.679)\end{array}$ \\
\hline $\begin{array}{l}\text { Central Asian } \\
\text { country }\end{array}$ & $\begin{array}{c}1.193 \\
(0.656)\end{array}$ & & & $\begin{array}{c}0.130 \\
(1.113)\end{array}$ & $\begin{array}{c}1.531 \\
(1.414)\end{array}$ \\
\hline Constant & $\begin{array}{c}-4.902 * * \\
(0.424)\end{array}$ & $\begin{array}{c}-4.255^{* *} \\
(0.433)\end{array}$ & $\begin{array}{c}-4.069 * * \\
(0.567)\end{array}$ & $\begin{array}{l}-1.626 \\
(0.972)\end{array}$ & $\begin{array}{l}-1.331 \\
(1.013)\end{array}$ \\
\hline Total observations & 26 & 26 & $24^{15}$ & 26 & 26 \\
\hline $\mathrm{R}^{2}$ & 0.77 & 0.76 & 0.75 & 0.48 & 0.48 \\
\hline
\end{tabular}

Note: Baltic countries are Estonia, Latvia and Lithuania, Transcaucasian countries are Armenia, Azerbaijan and Georgia, Central Asian countries are Kazakhstan, Kyrgyzstan, Tajikistan, Turkmenistan and Uzbekistan, reference group is Slavic countries with Belarus, Moldova, Russia and Ukraine. Standard errors calculated with clustering on countries. ${ }^{*}=$ significant at the $5 \%$ level, $* *=$ significant at the $1 \%$ level, robust standard errors in parentheses.

\footnotetext{
${ }^{15}$ Baltic countries are excluded.
} 
Table 5: Estimated emigration (dependent variable: $\log$ of emigrants)

\begin{tabular}{|c|c|c|c|c|c|}
\hline & (1) & (2) & (3) & (4) & (5) \\
\hline $\begin{array}{l}\text { Log of potential } \\
\text { number of emigrants }\end{array}$ & $\begin{array}{c}0.699 * * \\
(0.054)\end{array}$ & $\begin{array}{c}0.667 * * \\
(0.058)\end{array}$ & $\begin{array}{c}0.660 * * \\
(0.072)\end{array}$ & $\begin{array}{c}0.668 * * \\
(0.055)\end{array}$ & $\begin{array}{l}0.663^{*} \\
(0.067)\end{array}$ \\
\hline $\begin{array}{l}\text { Share of titular group } \\
\text { in emigration country }\end{array}$ & & & & & $\begin{array}{c}0.193 \\
(1.448)\end{array}$ \\
\hline $\begin{array}{l}\text { Log of ethnic group } \\
\text { size outside emigra- } \\
\text { tion country in FSU }\end{array}$ & $\begin{array}{c}0.410 * * \\
(0.079)\end{array}$ & & & & \\
\hline $\begin{array}{l}\text { Log of total ethnic } \\
\text { group size outside the } \\
\text { emigration country }\end{array}$ & & $\begin{array}{c}0.409 * * \\
(0.086)\end{array}$ & $\begin{array}{c}0.352 * * \\
(0.091)\end{array}$ & $\begin{array}{c}0.418 * * \\
(0.068)\end{array}$ & $\begin{array}{c}0.351 * * \\
(0.095)\end{array}$ \\
\hline Finns, Germans, Jews & $\begin{array}{c}2.160 * * \\
(0.335)\end{array}$ & $\begin{array}{c}0.864 \\
(0.442)\end{array}$ & $\begin{array}{c}0.876 \\
(0.444)\end{array}$ & $\begin{array}{l}0.855^{*} \\
(0.399)\end{array}$ & $\begin{array}{c}0.884 \\
(0.455)\end{array}$ \\
\hline "Russia" & $\begin{array}{c}0.071 \\
(0.149)\end{array}$ & $\begin{array}{l}-0.028 \\
(0.145)\end{array}$ & $\begin{array}{l}-0.172 \\
(0.109)\end{array}$ & & $\begin{array}{l}-0.184 \\
(0.158)\end{array}$ \\
\hline "Wealth" & $\begin{array}{l}-0.140 \\
(0.289)\end{array}$ & $\begin{array}{l}-0.133 \\
(0.265)\end{array}$ & $\begin{array}{c}-0.559 * * \\
(0.144)\end{array}$ & & $\begin{array}{c}-0.565 * * \\
(0.147)\end{array}$ \\
\hline "Growth" & $\begin{array}{c}0.130 \\
(0.165)\end{array}$ & $\begin{array}{c}0.144 \\
(0.138)\end{array}$ & $\begin{array}{c}0.116 \\
(0.143)\end{array}$ & & $\begin{array}{c}0.117 \\
(0.142)\end{array}$ \\
\hline "Transition" & $\begin{array}{l}-0.160 \\
(0.194)\end{array}$ & $\begin{array}{l}-0.151 \\
(0.183)\end{array}$ & $\begin{array}{l}-0.362 * \\
(0.153)\end{array}$ & & $\begin{array}{l}-0.351 * \\
(0.148)\end{array}$ \\
\hline Baltic country & $\begin{array}{c}0.213 \\
(0.450)\end{array}$ & $\begin{array}{l}-0.074 \\
(0.390)\end{array}$ & & $\begin{array}{l}-0.282 \\
(0.181)\end{array}$ & \\
\hline $\begin{array}{l}\text { Transcaucasian } \\
\text { country }\end{array}$ & $\begin{array}{l}1.725^{* *} \\
(0.423)\end{array}$ & $\begin{array}{l}1.681 * * \\
(0.394)\end{array}$ & & $\begin{array}{c}1.658 * * \\
(0.362)\end{array}$ & \\
\hline $\begin{array}{l}\text { Central Asian } \\
\text { country }\end{array}$ & $\begin{array}{c}0.880 \\
(0.624)\end{array}$ & $\begin{array}{c}0.805 \\
(0.586)\end{array}$ & & $\begin{array}{c}0.943 * * \\
(0.242)\end{array}$ & \\
\hline Constant & $\begin{array}{c}-5.016^{* *} \\
(0.899)\end{array}$ & $\begin{array}{c}-4.787 * * \\
(0.924)\end{array}$ & $\begin{array}{c}-3.682 * * \\
(0.964)\end{array}$ & $\begin{array}{c}-4.925^{* *} \\
(0.493)\end{array}$ & $\begin{array}{c}-3.818 * * \\
(1.119)\end{array}$ \\
\hline Total observations & 53 & 53 & 53 & 53 & 53 \\
\hline $\mathrm{R}^{2}$ & 0.90 & 0.90 & 0.85 & 0.89 & 0.87 \\
\hline
\end{tabular}

Note: Baltic countries are Estonia, Latvia and Lithuania, Transcaucasian countries are Armenia, Azerbaijan and Georgia, Central Asian countries are Kazakhstan, Kyrgyzstan, Tajikistan, Turkmenistan and Uzbekistan, reference group is Slavic countries with Belarus, Moldova, Russia and Ukraine. Standard errors calculated with clustering on countries. $*=$ significant at the $5 \%$ level, $* *=$ significant at the $1 \%$ level, robust standard errors in parentheses. 
Table 6: Estimated emigration - The role of ethnic Germans and Jews

\begin{tabular}{lcc}
\hline & $(1)$ & $(2)$ \\
\hline $\begin{array}{l}\text { Log of potential number of } \\
\text { emigrants }\end{array}$ & $0.685^{* *}(0.073)$ & $0.667 * *(0.069)$ \\
$\begin{array}{l}\text { Log of ethnic group size outside } \\
\text { emigration country in FSU }\end{array}$ & $0.314^{* *}(0.059)$ & \\
$\begin{array}{l}\text { Log of total ethnic group size } \\
\text { outside the emigration country }\end{array}$ & $1.843^{* *}(0.361)$ & $1.211^{* *}(0.333)$ \\
Jewish & $2.031 * *(0.423)$ & $0.854(0.438)$ \\
Ethnic German & $-0.220^{*}(0.089)$ & $-0.193(0.103)$ \\
"Russia" & $-0.511^{* *}(0.144)$ & $-0.557 * *(0.140)$ \\
"Wealth" & $0.151(0.138)$ & $0.129(0.144)$ \\
"Growth" & $-0.315(0.149)$ & $-0.353 *(0.152)$ \\
"Transition" & $-3.384 * *(0.754)$ & $-3.686 * *(0.953)$ \\
Constant & 53 & 53 \\
\hline Total observations & 0.87 & 0.87 \\
R 2 &
\end{tabular}

Note: Standard errors calculated with clustering on countries. ${ }^{*}=$ significant at the $5 \%$ level, $* *=$ significant at the $1 \%$ level, robust standard errors in parentheses. 


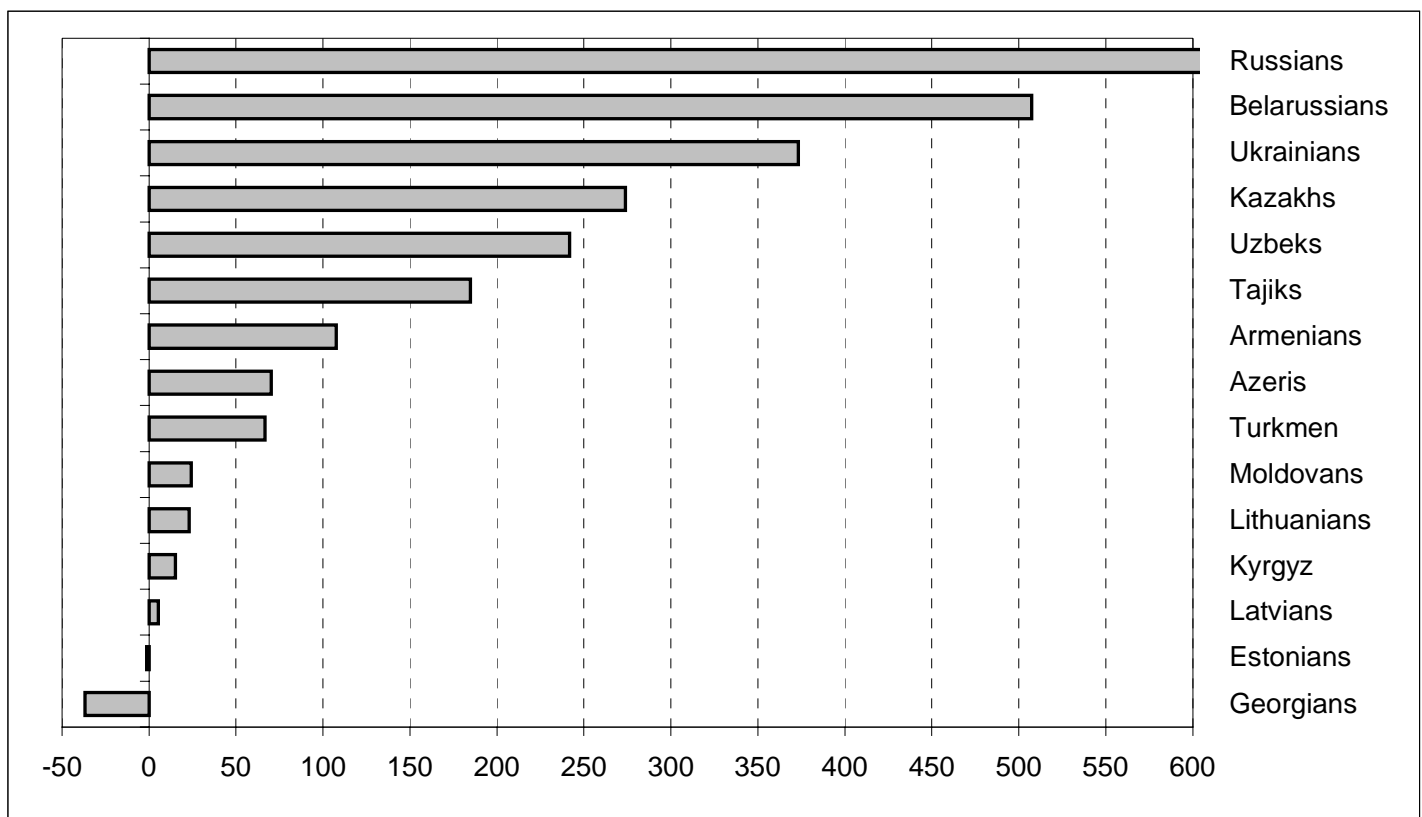

Figure 1: Return migration of national groups to their titular nation in the CIS, numbers in thousands, 1989-1999, 2.67 million Russians returned to Russia

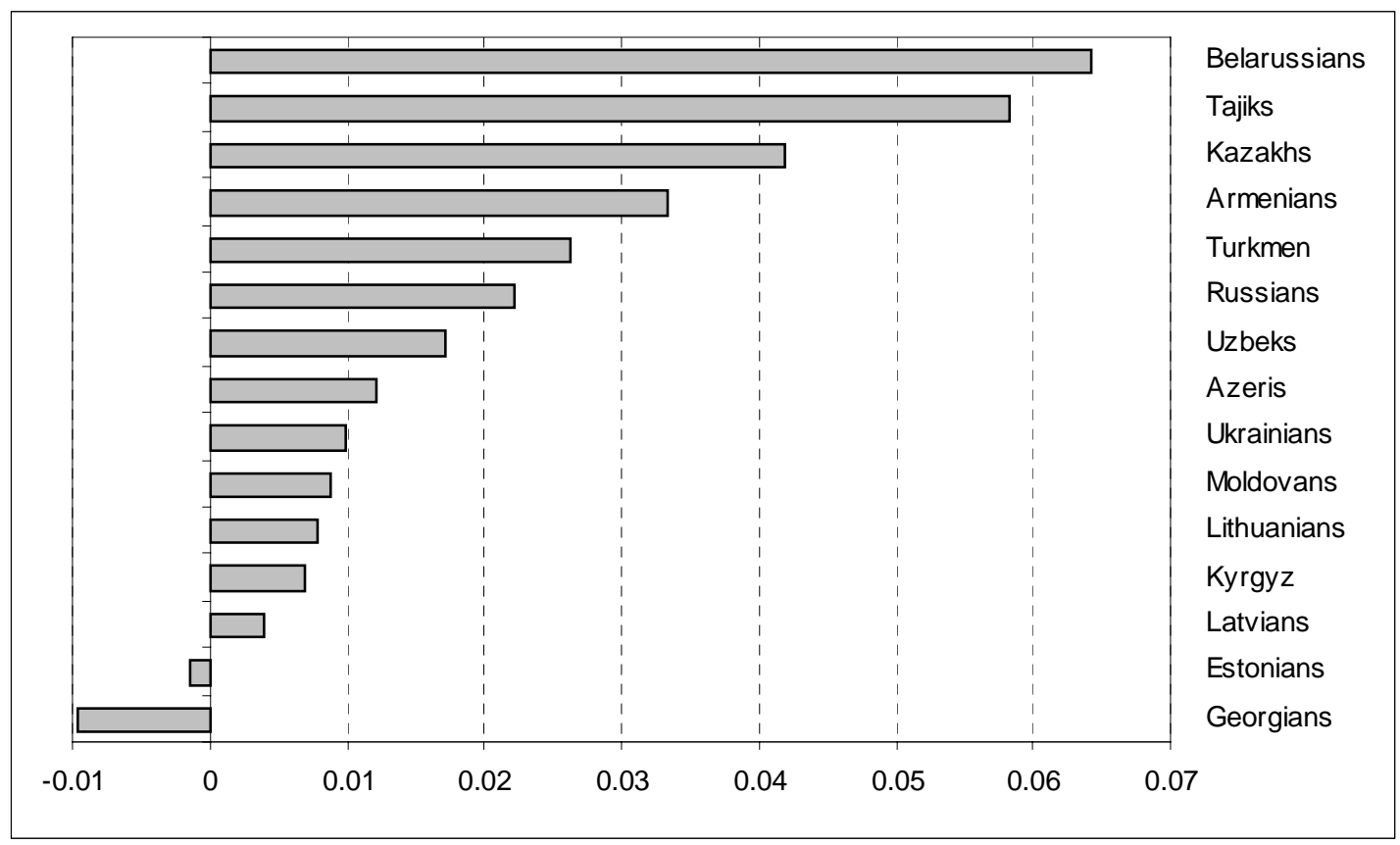

Figure 2: Return migration of national groups to their titular nation in the CIS, as percentage of the national population in the titular nation, 1989-1999 


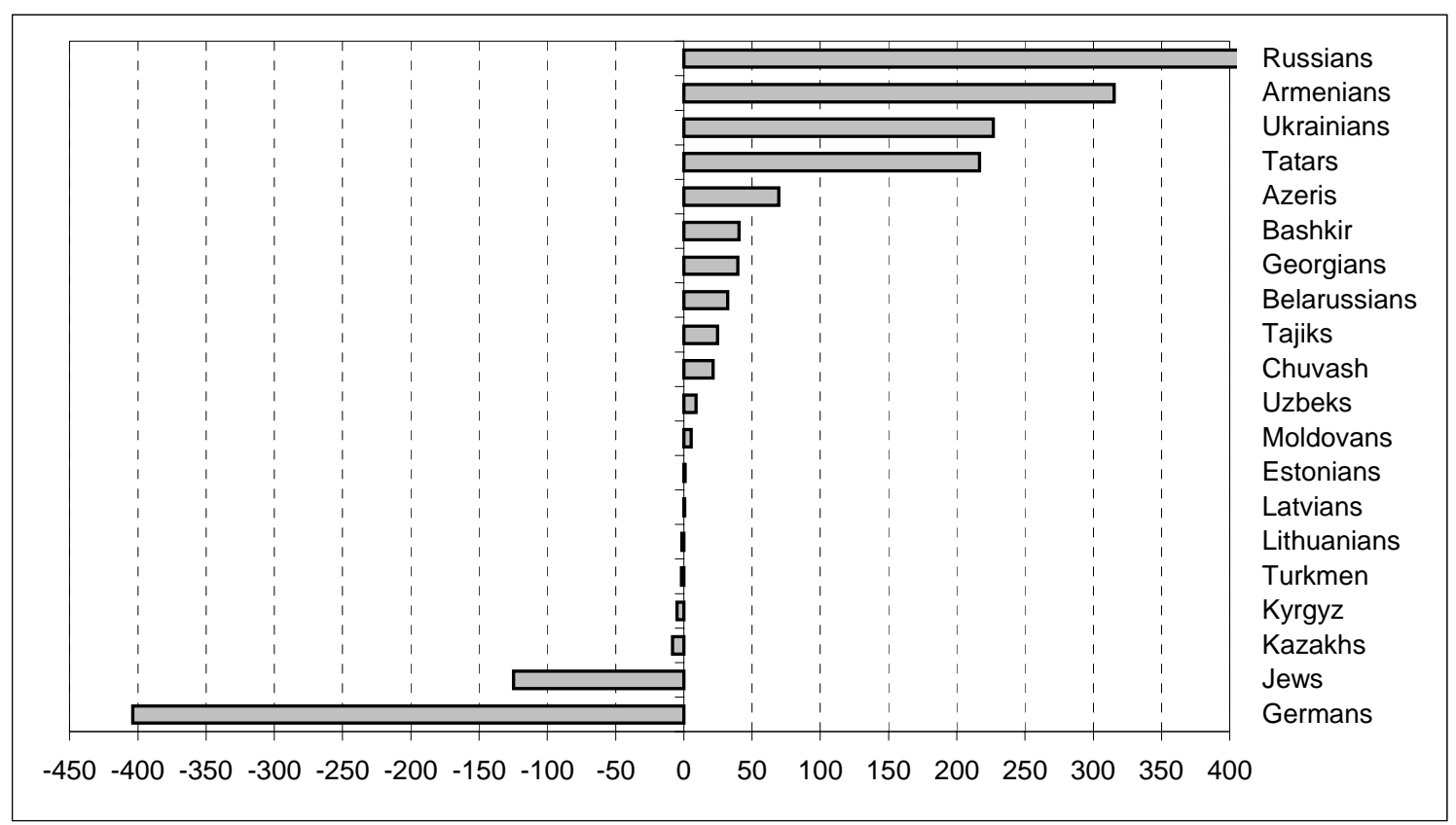

Figure 3: Net migration of national groups to Russia, numbers in thousands, 1989-1999, 2.67 million Russians migrated to Russia

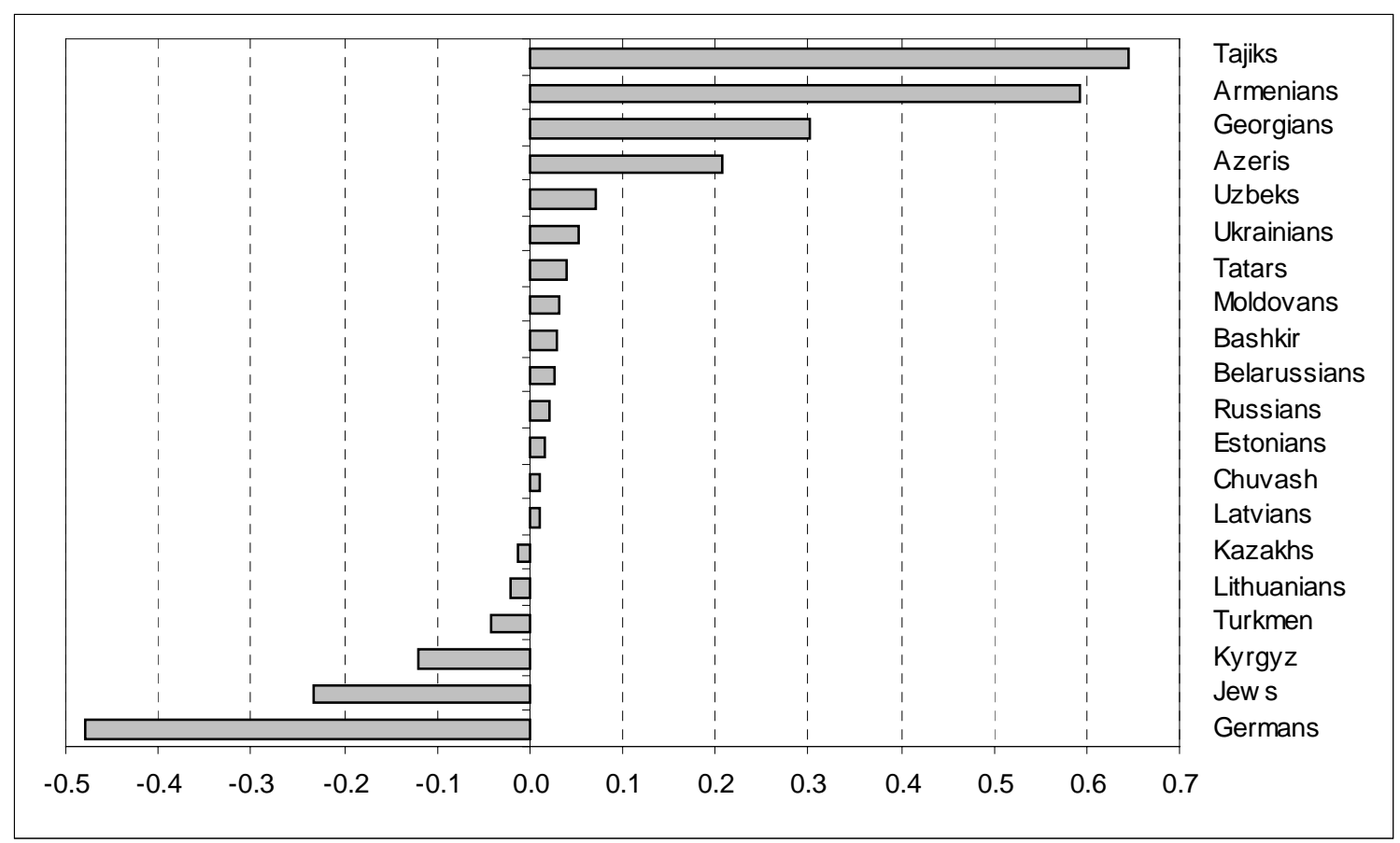

Figure 4: Net migration rates of national groups to Russia, as percentage of the respective national group in Russia in 1989, 1989-1999 


\section{IZA Discussion Papers}

\begin{tabular}{|c|c|c|c|c|}
\hline No. & Author(s) & Title & Area & Date \\
\hline 586 & $\begin{array}{l}\text { P. Díaz-Vázquez } \\
\text { D. Snower }\end{array}$ & $\begin{array}{l}\text { On-the Job Training and the Effects of Insider } \\
\text { Power }\end{array}$ & 3 & $09 / 02$ \\
\hline 587 & $\begin{array}{l}\text { H. Bonin } \\
\text { W. Kempe } \\
\text { H. Schneider }\end{array}$ & $\begin{array}{l}\text { Kombilohn oder Workfare? Zur Wirksamkeit } \\
\text { zweier arbeitsmarktpolitischer Strategien }\end{array}$ & 3 & $09 / 02$ \\
\hline 588 & M. Frölich & $\begin{array}{l}\text { Nonparametric IV Estimation of Local Average } \\
\text { Treatment Effects with Covariates }\end{array}$ & 6 & $09 / 02$ \\
\hline 589 & $\begin{array}{l}\text { S. Jurajda } \\
\text { K. Terrell }\end{array}$ & $\begin{array}{l}\text { Job Growth in Early Transition: Comparing Two } \\
\text { Paths }\end{array}$ & 4 & $09 / 02$ \\
\hline 590 & $\begin{array}{l}\text { H. Görg } \\
\text { E. Strobl } \\
\text { F. Walsh }\end{array}$ & $\begin{array}{l}\text { Why Do Foreign-Owned Firms Pay More? } \\
\text { The Role of On-the-Job Training }\end{array}$ & 2 & $10 / 02$ \\
\hline 591 & $\begin{array}{l}\text { H. Görg } \\
\text { E. Strobl }\end{array}$ & $\begin{array}{l}\text { Spillovers From Foreign Firms Through Worker } \\
\text { Mobility: An Empirical Investigation }\end{array}$ & 1 & $10 / 02$ \\
\hline 592 & J. Wagner & $\begin{array}{l}\text { Testing Lazear's Jack-of-All-Trades View of } \\
\text { Entrepreneurship with German Micro Data }\end{array}$ & 5 & $10 / 02$ \\
\hline 593 & $\begin{array}{l}\text { T. K. Bauer } \\
\text { P. J. Dross } \\
\text { J. P. Haisken-DeNew }\end{array}$ & Sheepskin Effects in Japan & 1 & $10 / 02$ \\
\hline 594 & $\begin{array}{l}\text { S. C. Wolter } \\
\text { M. Coradi Vellacott }\end{array}$ & $\begin{array}{l}\text { Sibling Rivalry: A Look at Switzerland with } \\
\text { PISA Data }\end{array}$ & 2 & $10 / 02$ \\
\hline 595 & $\begin{array}{l}\text { W. Arulampalam } \\
\text { A. L. Booth } \\
\text { M. L. Bryan }\end{array}$ & $\begin{array}{l}\text { Work-Related Training and the New National } \\
\text { Minimum Wage in Britain }\end{array}$ & 3 & $10 / 02$ \\
\hline 596 & $\begin{array}{l}\text { H. Görg } \\
\text { E. Strobl }\end{array}$ & $\begin{array}{l}\text { Relative Wages, Openness and Skill-Biased } \\
\text { Technological Change }\end{array}$ & 2 & $10 / 02$ \\
\hline 597 & $\begin{array}{l}\text { S. M. Fuess, Jr. } \\
\text { M. Millea }\end{array}$ & $\begin{array}{l}\text { Disentangling Pay and Productivity in a } \\
\text { Corporatist Economy: The Case of Germany }\end{array}$ & 5 & $10 / 02$ \\
\hline 598 & $\begin{array}{l}\text { D. Del Boca } \\
\text { A. Lusardi }\end{array}$ & $\begin{array}{l}\text { Credit Market Constraints and Labor Market } \\
\text { Decisions }\end{array}$ & 2 & $10 / 02$ \\
\hline 599 & $\begin{array}{l}\text { H. N. Mocan } \\
\text { B. Scafidi } \\
\text { E. Tekin }\end{array}$ & Catholic Schools and Bad Behavior & 5 & $10 / 02$ \\
\hline 600 & $\begin{array}{l}\text { J. S. Lauerová } \\
\text { K. Terrell }\end{array}$ & $\begin{array}{l}\text { Explaining Gender Differences in Unemployment } \\
\text { with Micro Data on Flows in Post-Communist } \\
\text { Economies }\end{array}$ & 4 & $10 / 02$ \\
\hline 601 & $\begin{array}{l}\text { S. Jurajda } \\
\text { K. Terrell }\end{array}$ & $\begin{array}{l}\text { What Drives the Speed of Job Reallocation } \\
\text { During Episodes of Massive Adjustment? }\end{array}$ & 5 & $10 / 02$ \\
\hline 602 & L. Locher & Migration in the Soviet Successor States & 2 & $10 / 02$ \\
\hline
\end{tabular}

An updated list of IZA Discussion Papers is available on the center's homepage www.iza.org. 